\title{
Implementation of Self-Assessment in Learning High School Geography in Lampung Selatan Regency
}

\author{
Zulkarnain \\ Geography Education \\ Lampung University \\ Lampung, Indonesia \\ zulkarnain.1960@fkip.unila.ac.id
}

\author{
Pargito \\ Geography Education \\ Lampung University \\ Lampung, Indonesia \\ pargito1959@fkip.ac.id
}

\author{
Dian Utami \\ Geography Education \\ Lampung University \\ Lampung, Indonesia \\ dian.utami@fkip.unila.ac.id
}

\begin{abstract}
This study aims to determine the extent of the implementation of self-assessment in high school geography learning in South Lampung district and what are the obstacles in the implementation of selfassessment. The research method used in this study is a descriptive qualitative research method. Data collection techniques using questionnaires, documentation, interviews. Analysis of the data used is descriptive analysis. The results of the study show: 1) Some teachers already have a self-assessment assessment of their students but it is carried out for cognitive aspects 2) Teachers feel burdened in making instruments for each indicator, teachers need a lot of time to think and develop instruments, the level of teacher confidence will the instrument filling by students is still lacking.
\end{abstract}

Keywords-Implementation, Learning Geography, Self-Assessment.

\section{INTRODUCTION}

The learning process is inseparable from three very important and basic things, namely making learning plans, carrying out learning activities, and conducting evaluations. Evaluation is very essential. Through evaluation the teacher can see and determine whether students have mastered the learning and the objectives have been achieved or not. Evaluation of learning in the 2013 curriculum refers to three aspects, namely cognitive, affective and psychomotor. To see achievement in learning is not only seen from the final result but also emphasizes the assessment process. A good and effective process assessment will not deny the existence of good learning outcomes. The quality of learning can be improved through improving the quality of assessment [1].

The objectives of the field of geography study include aspects and processes on Earth, causal relationships between spatial, human and environmental factors that are directed to be able to contribute to development both on a local, national, and international scale. Learning geography does not only contain theories and concepts that students must memorize, but more than that, geography learning contains insights on how humans are wise in treating nature. Thus the assessment in geography learning is important in knowing the achievement of affective aspects concerning attitudes.

Assessment in learning geography emphasizes one aspect, namely affective. Affective assessment is an assessment that refers to the realm of student attitudes. Affective assessment consists of assessment of spiritual attitudes and social attitudes. To find out the achievement of this affective assessment indicator cannot be measured with a test instrument but nontest, one of which is in the form of self- assessment. So far, the assessments made by teachers are limited to only measuring students' abilities on the cognitive aspect. It is still rare for teachers to use assessment instruments to measure students' abilities in the affective aspect.

One of the assessment techniques that can be used is self-assessment or self- assessment. Self-assessment is a self- assessment conducted by students. By using self-assessment students can assess their own competencies so that in the future students can determine improvement strategies if there are gaps found between the competencies they have and the competencies contained in the curriculum. Selfassessment techniques can be used not only to assess attitude competence but also cognitive and skills. This evaluation process can provide a reflection or selfreflection to assess self-quality in learning in order to maintain what is already optimal and improve what is less than optimal to become more optimal $[2,3]$. 
Self-assessment is an assessment technique. Effective formative because the information collected comes from the point of view of teachers and students. In addition, self-assessment is not only limited to selfevaluation, but students are also involved in finding ways in an effort to develop themselves. Thus, students become more responsible with their learning the steps in self- assessment are: Determining the competencies to be assessed, determining the assessment criteria to be used, Formulating the assessment format and assessment guidelines, Asking students to conduct self-assessments.

The use of self and peer assessment can have a positive impact on development person's personality, among others; can grow a person's self-confidence, because he is given the trust to judge himself and others, Realize his strengths and weaknesses, because when he makes an assessment, he must introspect his strengths and weaknesses Can encourage, familiarize, and train himself to be honest, because we are required to be honest and objective in conducting assessments, gain new experiences in learning activities, gain insight in conducting assessments, improve students' critical thinking $[4,5]$.

Self-assessment provides a great opportunity for students to be involved in learning, making them more aware of themselves, their competencies, the way they think, the strategies they have done, and then determining the goals to be achieved to improve their learning in connection with the results of the reflection of that recognition [6]. si self can understand that making mistakes is part of the learning process. Selfassessment can spur students to continue to be actively involved in their learning with a view to avoiding embarrassment to their peers [7].

Although it has good goals in assessment and has long been discussed, there are still many teachers who have not implemented self-assessment in learning [8,5]. Based on the results of researchers' interviews with geography teachers in South Lampung Regency, out of 30 respondents only 19 people or $63.3 \%$ had carried out self-assessment in learning.

Some of the obstacles faced in the implementation of self-assessment in learning include the problem of time and the level of honesty that is still lacking, and students feel less confident in assessing their own work. Therefore, a way is needed to conduct an assessment without spending hours at school, not hampering material that has not been conveyed, the problem of the large number of students being resolved and being able to minimize the level of student dishonesty and students are more open in assessing their own work [9].
Based on the explanation above, this study aims to determine the extent of the implementation of selfassessment in high school geography learning in South Lampung district and what are the obstacles in the implementation of self-assessment.

\section{METHOD}

The research method used in this research is descriptive qualitative research method. Descriptive qualitative aims to describe the phenomena as they are, showing more characteristics, the quality of the interrelationships between activities [10]. Qualitative descriptive research method used in this study.

The subjects in this study were high school geography teachers in South Lampung district for the $2020 / 2021$ academic year, while the object of the research was the implementation of self- assessment in high school geography learning in South Lampung district. Research data collection was carried out through in-depth interviews, namely through the process of obtaining information for research purposes by means of question and answer while face to face between the interviewer and the respondent, with or without using interview guidelines where the interviewer and informant were involved in a relatively long social life. This interview was conducted to obtain accurate information about the obstacles faced by teachers and also the efforts made in implementing the geography learning process. The data analysis technique used in this research is descriptive data analysis technique, without using statistical formulas.

\section{RESEARCH RESULT}

The assessment that is focused on this discussion is self-assessment or self- assessment. This assessment is considered to have power in the formation of a positive personal character in addition to students having knowledge and skill competencies. Self- assessment can be used to measure students' self-efficacy in aspects of attitudes, knowledge, and skills. For example, the Core Competencies described in the basic competencies of each lesson already contain operational attitude measurement verbs. The application of self-assessment as a formative assessment where the assessment is an observation during the learning process and focuses on a process.

The implementation of authentic assessment has actually been carried out by geography teachers but self- assessment or self-assessment carried out by students for the students themselves are still not widely implemented. Self-assessment and learning activities have not been widely carried out, because teachers mostly use assessments that are tests, quizzes or questions and answers and the assessment is mostly done through observations by teachers with observation sheets. The self-assessment model is an 
innovative assessment model that is currently developing in the world of education this assessment model can have a positive impact on the personality development of students.

The advantages of using self-assessment and peer assessment in the classroom, among others, can foster students' self- confidence, because they are given the trust to evaluate and assess themselves, students realize their strengths and weaknesses, because when they do an assessment they must introspect on their strengths. and weaknesses they have and can encourage, familiarize, and train students to be honest, because they are required to be objective in conducting assessments.

Some teachers actually already have a selfassessment assessment of their students during learning, by asking students to correct their own test results using the answer key that has been made by the teacher, with this activity students indirectly know the weaknesses and strengths in working on the questions. students who have been tested must be objective and honest in this assessment activity. For teachers themselves, this self-assessment activity is more effective because the grades can be directly known without having to correct one by one the answer sheets from the students. In addition, selfassessment is also used to assess the extent to which students understand the learning delivered and what competencies they feel have not been mastered.

Self-assessment is an innovative form of assessment that supports learning activities. The results of previous studies show that the effectiveness of self- assessment can be seen from the positive influence on student learning outcomes, including increased learning outcomes and learning motivation $[11,12]$. A good self-assessment will produce good learning outcomes, if followed by a follow-up of what has not been mastered. Good self-assessment techniques are also able to lead to self-awareness of their strengths and weaknesses [11].

All geography teachers agree on the effectiveness of using self-assessment both as an authentic assessment effort in large classes and large numbers of students, but that does not mean teachers agree to implement it. Although self-assessment has advantages and advantages in the assessment process, there are several things that become obstacles in its implementation. Teachers feel burdened in making instruments for each indicator. Teachers need a lot of time to think and arrange instruments. The level of teacher confidence in the contents of the instrument by students is still lacking. Often students are not serious in filling out the instrument.

\section{CONCLUSION}

The conclusions of this study are; some teachers already have a self-assessment assessment of their students but it is carried out for the cognitive aspect. The obstacles faced by teachers in implementing selfassessment are that teachers feel burdened in making instruments for each indicator, teachers need a lot of time to think and develop instruments, the level of teacher confidence in the instrument filling by students is still lacking. Often students are not serious in doing it.

\section{REFERENCES}

[1] Kumaidi, Implementation of Authentic Assessment in Classroom Learning. National Seminar on Implementation of Assessment and Implementation of Curriculum 2013. Jakarta: Jakarta State University, 2014.

[2] Fauziya, Diena San, and Alfa Mitri Suhara, "Evaluation of Learning Through Writing Reflective Journals Based on Self-Assessment at Pbs. Indonesia Stkip Siliwangi." $P 2 M$ STKIP Siliwangi 2(1):46, 2015.

[3] Wahyuningsih, Reni, Sri Wahyuni, Albertus Djoko Lesmono, Program Students, and Education Studies. 2013. “1) 2) 2) 1)." 3:338-43.

[4] Hidayat, Adityawarman, "Meta Analysis: The Importance of Self and Peer Assessment in Learning." Journal of Basiced 2(1):95-101, 2018.

[5] Wijayanti, Anita, "The Effectiveness of Self Assessment and Peer Assessment in Character Building Students." Reality 15 (Volume 15, No. 2):1-14, 2017.

[6] Yusuff, Kazeem B, "Does Self-Reflection and PeerAssessment Improve Saudi Pharmacy Students' Academic Performance and Metacognitive Skills?" Saudi Pharmaceutical Journal 23(3):266-75, 2015.

[7] Maryellen Weimer, Focus on Learning, Transform Teaching, Change. The Magazine of Higher Learning. 35(5):48-54, 2003

[8] Auliya, Jihan, Gusti Ayu Mahayukti, and I. Nyoman Gita, "Application of Self-Assessment to Improve Students' SelfEfficacy in Learning Mathematics." Scientific Journal of Education and Learning 2(2), 2018.

[9] Gumilar, et al, Application of Peer Assessment and Self Assessment on Hydrocarbon Formative Tests for Feedback for Class X High School Students. Journal of Mathematics and Natural Sciences Teaching. ISSN 2443-3616 Vol 18(1):10-19, 2013

[10] N. S. Sukmadinata. Metode Penelitian Pendidikan. Bandung: Remaja Rosadakarya. 2011.

[11] Lisnawati, Santi, and Halimah Siregar, "INFLUENCE OF SELF ASSESSMENT ON LEARNING OUTCOMES INTRODUCTION Writing Scientific Papers and Publication of Scientific Papers Become An Inseparable One From Research Activities. Writing Scientific Papers and Publication of Scientific Work Becomes a National Problem Y." 9(2), 2018

[12] Tamaela, Elsina S., and Venty Sopacua, "Self Assessment (Key to the Success of Prospective Teacher Students in Analyzing Concepts)." Biocell: Biology Science and Education 9(1):60, 2020 